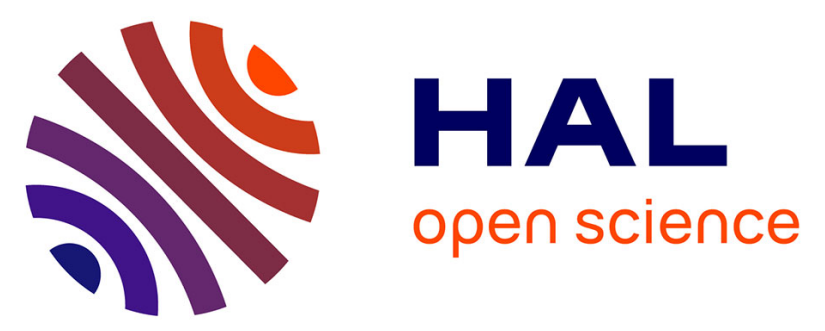

\title{
Nanoprobe Synthesized by Magnetotactic Bacteria, Detecting Fluorescence Variations under Dissociation of Rhodamine B from Magnetosomes following Temperature, $\mathrm{pH}$ Changes, or the Application of Radiation
}

Edouard Alphandéry, Darine Abi Haidar, Olivier Seksek, Maxime Thoreau, Alain Trautmann, Nadege Bercovici, Florence Gazeau, François Guyot, Imène Chebbi

\section{To cite this version:}

Edouard Alphandéry, Darine Abi Haidar, Olivier Seksek, Maxime Thoreau, Alain Trautmann, et al.. Nanoprobe Synthesized by Magnetotactic Bacteria, Detecting Fluorescence Variations under Dissociation of Rhodamine B from Magnetosomes following Temperature, $\mathrm{pH}$ Changes, or the Application of Radiation. ACS Applied Materials \& Interfaces, 2017, 9 (42), pp.36561-36572. 10.1021/acsami.7b09720 . hal-01620232

\section{HAL Id: hal-01620232 \\ https://hal.sorbonne-universite.fr/hal-01620232}

Submitted on 20 Oct 2017

HAL is a multi-disciplinary open access archive for the deposit and dissemination of scientific research documents, whether they are published or not. The documents may come from teaching and research institutions in France or abroad, or from public or private research centers.
L'archive ouverte pluridisciplinaire HAL, est destinée au dépôt et à la diffusion de documents scientifiques de niveau recherche, publiés ou non, émanant des établissements d'enseignement et de recherche français ou étrangers, des laboratoires publics ou privés. 


\title{
A Nanoprobe Synthesized by Magnetotactic Bacteria, Detecting Fluorescence Variations under Dissociation of Rhodamine B from Magnetosomes following Temperature, pH Changes, or the Application of Radiations.
}

\author{
Edouard Alphandery ${ }^{+, \perp, *}$, Darine Abi-Haidar ${ }^{++,++++}$, Olivier Seksek ${ }^{++}$, Maxime Thoreau ${ }^{+++}$, Alain \\ Trautmann $^{+++}$, Nadege Bercovici ${ }^{+++}$, Florence Gazeau ${ }^{+++}$, François Guyot $^{+}$, Imène Chebbi ${ }^{\perp}$
}

${ }^{+}$Institut de minéralogie, de physique des matériaux et de cosmochimie, UMR 7590 CNRS, Sorbonne Universités, UPMC, University Paris 06, Muséum National d'Histoire Naturelle, 4 Place Jussieu, 75005, Paris, France.

${ }^{\perp}$ Nanobacterie SARL, 36 boulevard Flandrin, 75116, Paris, France.

${ }^{++}$Laboratoire d'imagerie et modélisation en neurobiologie et cancérologie, UMR 8165, Paris-Saclay University, Rue des Adèles, Campus d'Orsay Bâtiment 440, 91405, Orsay, France.

${ }^{+++}$Institut Cochin, 22 rue Méchain, 75014, Paris, France.
${ }^{++++}$Laboratoire de matière et systèmes complexes, MSC, Université Paris Diderot, bâtiment Condorcet, case 7056, 75205 Paris Cedex 13, France.
${ }^{+++++}$Paris Diderot University, F-75013, Paris, France.

*Corresponding author Email address:

edouardalphandery@hotmail.com

KEYWORDS: magnetosomes, magnetotactic bacteria, fluorescent probe, thermometer, fluorescence, nanomedicine, magnetic hyperthermia, alternating magnetic field. 


\begin{abstract}
We report a method of fabrication of fluorescent magnetosomes, designated as MCR400, in which $400 \mu \mathrm{M}$ of rhodamine $\mathrm{B}$ are introduced in the growth medium of AMB-1 magnetotactic bacteria and fluorescent magnetosomes are then extracted from these bacteria. These fluorescent magnetosomes behave differently from most fluorescent nanoprobes, which often lead to fluorescence losses over time due to photo-bleaching. Indeed, when MCR400 are heated to $30-90{ }^{\circ} \mathrm{C}$, brought to an acidic $\mathrm{pH}$, or exposed to radiations, we observed that their fluorescence intensity increased. We attributed this behavior to the dissociation of rhodamine B from the magnetosomes. Interestingly, enhanced fluorescence was also observed in vitro when MCR400 were mixed with either primary macrophages or tumor cells (TC1-GFP or RG2-Cells) or in vivo when MCR400 were introduced in rat glioblastoma. We showed that MCR400 internalize in tumor and immune cells (macrophages) leading to enhanced fluorescence, suggesting that fluorescent magnetosomes could be used during cancer treatments such as magnetic hyperthermia to image cells of interest such as immune or tumor cells.
\end{abstract}




\section{INTRODUCTION}

During the past few years, the design of nano-scale fluorescent probes has been considerably improved to yield a high level of sophistication ${ }^{1}$. With these probes, it is possible to detect locally a wide range of different parameters including intracellular $\mathrm{pH}^{2}, \mathrm{pH}$ in solution ${ }^{3,4}$, the presence of a cell membrane or organelles ${ }^{5}$, molecules of interest, e.g. folic acid ${ }^{6}$, the release of substances from nanoparticles, e.g. drugs such as doxorubicin ${ }^{7}$, or toxic compounds such as mercury ${ }^{8}$, temperature variations due for example to changes in intracellular $\mathrm{Ca}^{2+}$ concentration ${ }^{9}$, or to the application of a radiation. ${ }^{10}$ Detection can rely on the variation of the fluorescence intensity, wavelength ${ }^{11}$, or lifetimes ${ }^{7}$, with such parameter. These probes were made of various inorganic ${ }^{3}$, organic ${ }^{12,13}$ or biodegradable ${ }^{14}$, nano-materials, in which fluorescent molecules could either be self-assembled into a nanomaterial ${ }^{11}$, or bound, covalently or not, to existing nanoparticles ${ }^{15}$. They were either directly exposed to a potentially degrading surrounding environment or embedded in a protecting matrix, e.g. silica $^{15}$. Nano-assembly could result in enhanced $^{16}$, or quenched ${ }^{17,18,19}$ fluorescence. Mechanism responsible for the fluorescence properties of these probes was often reported to involve electron or energy transfer ${ }^{20,21,22}$, which is enhanced due to fluorescent molecules being in close proximity with each other or with nanoparticles. These probes were also functionalized to target specific cells, e.g. RGD peptides were conjugated to fluorescent nanoparticles to target $\alpha_{v} \beta_{3}$ integrin overexpressed in certain cancer cells ${ }^{13}$. Their design could yield fluorescence emission at several wavelengths ${ }^{23}$, or combine fluorescence with other imaging methods, such as positron emission tomography ${ }^{24}$. In some cases, nanometric fluorescent probes were used for detection and treatment purposes, using for example photo-thermal therapy (PTT) or photodynamic therapy $(\mathrm{PDT})^{25}$. Previous studies mainly reported the properties of chemically synthesized fluorescent nano-probes. However, it has been shown that a species of bacterium, called magnetotactic bacterium, synthetizes iron oxide nanoparticles called magnetosomes ${ }^{26}$, with larger sizes, better crystallinity, and superior magnetic properties and heating power under the application of an alternating magnetic field compared with most chemically synthesized nanoparticles ${ }^{27}$. Due to these properties, magnetosomes were successfully tested for a wide range of different medical applications, including magnetic 
hyperthermia and magnetic resonance imaging ${ }^{28,29,30}$. Fabrication of fluorescent magnetosomes were previously described, either involving genetic manipulations of magnetotactic bacteria to produce magnetosomes tagged with green fluorescent proteins ${ }^{31,32}$, or a chemical hydrophobic interaction between a fluorophore (DiI) and magnetosomes extracted from magnetotactic bacteria ${ }^{33}$. However, genetic engineering could hardly yield a high magnetosome production yield, while fluorescent magnetosomes obtained by chemical adsorption were shown to image cells but not to detect other parameters $^{33}$.

In this study, we introduced a new method to synthesize fluorescent magnetosomes in which a solution of rhodamine $\mathrm{B}$ was introduced in the growth medium of magnetotactic bacteria in addition to the iron source $^{34}$. Following their extraction from magnetotactic bacteria, magnetosomes appeared to be associated with rhodamine B. They were designated as MCR400. We compared the properties of MCR400 with those of two other types of magnetosomes in which we attempted to chemically associate rhodamine $\mathrm{B}$ to the magnetosomes either via a reaction between rhodamine $\mathrm{B}$ and magnetosomes (MC@RhB-1) or through direct adsorption of rhodamine B at magnetosome surface (MC@RhB-2). Absorption and fluorescent properties of the supernate of the suspensions containing MCR400, MC@RhB-1, and MC@RhB-2, obtained after magnetic separation, were studied to examine the presence (or not) of rhodamine B in the supernate and hence to deduce if rhodamine B has remained associated with the magnetosomes after magnetic separation. These properties were also studied when these suspensions were exposed to changes in temperature, $\mathrm{pH}$ or various levels of radiations. We examined if fluorescence changes were occurring to determine if the probe could be used to detect such parameters. Besides studies in solution, the fluorescent probe was also brought into contact with cells and administered inside the brain of rats to study fluorescent changes under these conditions and explore the use of this probe in an in vitro or in vivo environment.

\section{EXPERIMENTAL SECTION}

\subsection{Synthesis of non-fluorescent chains of magnetosomes extracted from magnetotactic} bacteria (MC). Magnetospirillum magneticum AMB-1 magnetotactic bacteria were obtained from 
ATCC (ATCC 700274) and grown under microaerobic conditions at $30{ }^{\circ} \mathrm{C}$ in a growth medium slightly different from the MSGM medium (ATCC medium 1653). TEM images of whole magnetotactic bacteria, chains of magnetotosomes, and histograms of magnetosome sizes are presented in Fig. 1. In one litter, this medium contained $0.68 \mathrm{~g}$ of monobasic potassium phosphate, $0.85 \mathrm{~g}$ of sodium succinate, $0.57 \mathrm{~g}$ of sodium tartrate, $0.083 \mathrm{~g}$ of sodium acetate, $225 \mu \mathrm{l}$ of $0.2 \%$ resazurin, $0.17 \mathrm{~g}$ of sodium nitrate, $0.04 \mathrm{~g}$ of L-ascorbic acid, $2 \mathrm{ml}$ of a $10 \mathrm{mM}$ iron quinate solution, $10 \mathrm{ml}$ of a solution of Woolf vitamins and $5 \mathrm{ml}$ of a solution of Woolf minerals. The $\mathrm{pH}$ of the culture medium was adjusted to 6.85 using a $1 \mathrm{M}$ sodium hydroxide solution. The bacteria were collected during the stationary phase and concentrated using a tangential flow filtration column (mPES, 500KDa) with a flow rate of $950 \mathrm{~mL} / \mathrm{min}$ and then washed 5 times for 30 minutes with a solution of Phosphate buffer saline at $\mathrm{pH} 7.4(137 \mathrm{mM} \mathrm{NaCl}, 2.7$ $\mathrm{mM} \mathrm{KCl}, 10 \mathrm{mM} \mathrm{Na} 2 \mathrm{HPO} 4,1.76 \mathrm{mM} \mathrm{KH} 2 \mathrm{PO} 4)$. Bacteria were collected by centrifugation at $4000 \mathrm{rpm}$ for 1 hour, the supernatant was removed and the bacteria were re-suspended in $50 \mathrm{mM}$ Tris- $\mathrm{HCl}$ buffer solution at pH 7.4 and diluted to yield an optical density of 5 at $600 \mathrm{~nm}$. To lyse cell membranes and extract magnetosomes from the bacteria, the bacterial suspension was sonicated at $30 \mathrm{~W}$ at $5{ }^{\circ} \mathrm{C}$ during 60 minutes with pulses of $2 \mathrm{sec}$. and an interval between pulses of $1 \mathrm{sec}$. Following sonication, magnetosome chains were magnetically isolated from cellular debris using a neodymium magnet. The supernatant containing the cellular debris was removed and magnetosome chains (MC) were washed five times magnetically with a $50 \mathrm{mM}$ Tris- $\mathrm{HCl}$ buffer solution at $\mathrm{pH} 7.4$ and then fifteen times with Millipore ${ }^{\circledR}$ water. They were finally re-suspended in Millipore ${ }^{\circledR}$ sterile water to obtain a suspension of MC.

2.2. Instrumentation. Electron transmission microscopy images of whole bacteria, MC@RhB-1, MC@RhB-2, and MCR400 were obtained with a JEM-2100 from JEOL. For that, $5 \mu 1$ of a suspension of whole bacteria, MC@RhB-1, MC@RhB-2, and MCR400, were deposited on top of a carbon grid and dried. Size distributions of magnetosomes in MC@RhB-1, MC@RhB-2, and MCR400, were measured over 300 magnetosomes and plotted in histograms. For studies in solution, the absorption of the different suspensions was measured by a Varian Cary 3E UV-Vis spectrophotometer and the 
fluorescence of these suspensions was detected using Aminco-Bowman 2 spectrofluorimeter (Edison, NJ). For imaging cells in the presence of MCR400, we either used an inverted microscope (TE2000-E; Nikon) equipped with a 20x objective, for optical imaging or a JEOL JEM ARM 200F TEM for transmission electron imaging. For in vivo studies, we excited the section of brain tissues at $405 \mathrm{~nm}$ and collected the fluorescence between $400 \mathrm{~nm}$ and $700 \mathrm{~nm}$ using an optical fiber that we positioned above different regions of the tissue.

2.3. Optical setup: spectral measurement of fluorescence. A pulsed diode laser emitting at $405 \mathrm{~nm}$ of $40 \mathrm{MHz}$ with a power of $1 \mathrm{mw}$ from PicoQuant (GmbH, Berlin, Germany) was used for excitation. A bi-fibered configuration was employed for excitation and collection positioned $1.5 \mathrm{~mm}$ above the specimen. The fibres used for excitation and collection had a core diameter of $200 \mu \mathrm{m}$ and $365 \mu \mathrm{m}$, respectively, with a numerical aperture of 0.22 . The spatial resolution was of $500 \mu \mathrm{m}$. Collected fluorescence signal was sent toward a computer controlled cooled spectrometer (Ocean optics QP600-1UV-VIS) for spectroscopic analysis. ${ }^{35}$ Spectral acquisition was accomplished for several longitudinal lines of each sample using a specific mechanical support mounted on a motorized micro-translator stage (Thorlabs, Newton, USA) and it lasted 5 to 10 minutes per sample.

2.4. Heating studies in solution. In a first experiment, the different suspensions were heated using a heating bath (QBD2, Grant) at different temperatures from $20{ }^{\circ} \mathrm{C}$ to $90{ }^{\circ} \mathrm{C}$, for different times of 0 to 240 minutes. To verify that we have reached the desired temperature, we measured the temperatures of the suspensions using a thermocouple (physitemp, therms usb). Following heat treatment, we isolated the supernate from the nanoparticles using a Neodinum magnet that attracted the nanoparticles and we measured the absorption of the supernate. We then measured the absorption of the different suspensions between $400 \mathrm{~nm}$ and $700 \mathrm{~nm}$ containing $28 \mu \mathrm{g}$ in iron of MC, MCR400, MC@RhB-1, and MC@RhB-2 in $1 \mathrm{~mL}$ (Figs. 2(a) to 2(c)). In a second experiment, the different suspensions were heated as described above and we measured: i), the absorption of suspensions containing $116 \mu \mathrm{g} / \mathrm{mL}$ of MC@ $\mathrm{RhB}-1$ or MCR400 or of their supernate for different heating times and heating temperatures (Figs. 3(a) to 3(c)), ii), the concentration of rhodamine B in the supernate after heat treatment of the MCR400 suspension 
(Fig. 3(d)), iii), the fluorescence of the suspension containing $116 \mu \mathrm{g} / \mathrm{mL}$ in iron of MCR400 or $5 \mu \mathrm{M}$ of rhodamine B, which was exited at $405 \mathrm{~nm}$ and fluorescence were collected between 550 and $650 \mathrm{~nm}$, (Figs. 3(e), 3(f) and S1).

2.3. Irradiation studies in solution. Samples containing $400 \mu \mathrm{g} / \mathrm{mL}$ in iron oxide of MCR 400 or 125 $\mu \mathrm{M}$ of rhodamine $\mathrm{B}$ were irradiated using a Faxitron irradiator dosimeter $(160 \mathrm{kV}, 6.3 \mathrm{~mA}$ and without filter, 67.5 Gy/min), using irradiation doses ranging from 0 to $1350 \mathrm{~Gy}$. The fluorescence of the supernate of irradiated MCR400, obtained after magnetic separation, and of irradiated rhodamine B was measured (Fig. 4). Samples were exited at $405 \mathrm{~nm}$ and fluorescence was collected between 550 and 650 nm.

2.4. Fluorescence studies as a function of pH. pH of $1 \mathrm{~mL}$ suspensions containing MCR400, the supernate of MCR400, or rhodamine B was varied between 2 and 12 using a $\mathrm{NaOH}$ or $\mathrm{HCl}$ solution. The fluorescence spectra of these suspensions were then measured between 551 and $650 \mathrm{~nm}$ for $800 \mu \mathrm{l}$ suspensions after excitation at $550 \mathrm{~nm}$.

2.5 Cells. To isolate murine peritoneal macrophages, C57BL/6 were injected i.p. with zymosan $(200 \mu 1$, $5 \mathrm{mg} / \mathrm{ml}$ ). Three days later, the mice were sacrificed and their peritoneal cavity washed with $4 \mathrm{ml}$ of icecold PBS including 2 mM EDTA.

The murine fluorescent tumor cell line $\mathrm{TC} 1-\mathrm{GFP}^{36}$ were maintained in culture in complete RPMI, including 10\% FCS (GE Healthcare), antibiotics (Penicillin 50U/ml, Streptomycin 50 $\mu \mathrm{g} / \mathrm{ml}, \mathrm{GIBCO}$ ), L-Glutamine (4 mM, GIBCO) and Sodium Pyruvate (1 mM, GIBCO).

RG2 cells were obtained from American Type Culture Collection. Cell lines were grown in Dulbecco's modified Eagle's medium (DMEM) supplemented with 10\% fetal calf serum (FCS), 2 mM L-glutamine, $1 \mathrm{mM}$ sodium pyruvate, $50 \mathrm{U} / \mathrm{ml}$ streptomycin (all obtained from Life Technologies Inc.), at $37{ }^{\circ} \mathrm{C}$ in a 5\% CO2 humidified atmosphere, until they reached $90 \%$ confluency. The medium was removed and the cells were harvested using trypsin (0.04\% trypsin / EDTA). The cells were centrifuged at $800 \mathrm{rpm}$ for 5 min, suspended in PBS to final concentration of $3 \times 10^{3}$ RG2 cells $/ \mu \mathrm{L}$. 
U87-MG cells were obtained from American Type Culture Collection. Cell lines were grown in Dulbecco's modified Eagle's medium (DMEM) supplemented with 10\% fetal calf serum (FCS), 2 mM L-glutamine, $1 \mathrm{mM}$ sodium pyruvate, $50 \mathrm{U} / \mathrm{ml}$ streptomycin (all obtained from Life Technologies Inc.), at $37{ }^{\circ} \mathrm{C}$ in a $5 \% \mathrm{CO}_{2}$ humidified atmosphere, until they reached $90 \%$ confluency.

2.6 In vitro optical imaging studies. $210^{4} \mathrm{TC} 1$-GFP cells were seeded in a glass-bottomed culture dish (35 mm) for 24 hours, and treated with $350 \mu \mathrm{g} / \mathrm{mL}$ in iron oxide of MCR400 during 15 min. For fluorescence imaging, images were obtained with an inverted microscope (TE2000-E; Nikon) equipped with a 20x objective, and the Metamorph imaging software. Image analysis was done with Image J.

2.7 In vitro TEM studies. U87-Luc were seeded on a 12 -well culture plate for $24 \mathrm{~h}$ and treated with 3 $\mu \mathrm{g} / \mathrm{mL}$ in iron. $10^{6}$ from fixed cell suspensions were washed once with cacodylate buffer $(0.1 \mathrm{M})$, fixed with glutaraldehyde $(2.5 \%)$ at $4{ }^{\circ} \mathrm{C}$ for $60 \mathrm{~min}$ and washed with cacodylate buffer. Samples were then postfixed with $1 \%$ osmium tetroxide containing $1.5 \%$ potassium cyanoferrate, gradually dehydrated in ethanol (30\%-100\%) and embedded in Epon. Thin sections (80 nm) were collected onto 200 mesh cooper grids, and counterstained with lead citrate before examination with a Zeiss EM 902 transmission electron microscope at 80 KV (MIMA2-plateau de MET- unité 1196 GPL-Jouy-en-Josas). Microphotographies were acquired using Mega-View III CCD camera and analyzed with ITEM software (Eloïse SARL - Roissy CDG- France).

2.3. In vivo fluorescence studies. To evaluate if MCR400 can be used as $\mathrm{pH}$ probe in vivo, 4 rats were used. The rat 1 is a healthy rat euthanized at the same time as rat 2 . Rats 2 to 4 received $5 \mu l$ of a suspension containing $3.10^{3}$ RG-2 cells, implanted using a stereotactic helmet through the left hemisphere (2 mm lateral and anterior to bregma) to a depth of $4 \mathrm{~mm}$. Rat 2 was not treated and euthanized 18 days after the implantation of the cells. Rats 3 and 4 received $14 \mu$ of a suspension of MCR400 at a concentration of $668 \mu \mathrm{g} / \mathrm{mL}$ in iron oxide fourteen days following tumor cell implantation. Rats 3 and 4 were euthanized 2 hours and 4 days following MCR400 administration, respectively. Brains of these rats were then extracted and cut into $3 \mathrm{~mm}$ thick slices.

\section{RESULTS AND DISCUSSION}


Fluorescent magnetosomes were synthesized using three different methods that are summarized in the schematic diagrams of Scheme 1.

\subsection{Preparation of dissociating probes: synthesis of fluorescent magnetosomes, designated as} MCR400, by introducing rhodamine $B$ in the growth medium of magnetotactic bacteria. Magnetotactic bacteria synthesize intracellular well-crystallized iron oxide nanoparticles with better magnetic properties than most chemically synthesized iron oxide nanoparticles. ${ }^{37}$ This is achieved by introducing a source of iron in the growth medium of these bacteria, which penetrates inside these bacteria and crystallizes into nanominerals. In this work, the source of iron was mixed with a solution of $400 \mu \mathrm{M}$ rhodamine $\mathrm{B}$ to produce fluorescent magnetosomes, designated as MCR400. Growth of magnetotactic bacteria was carried out as described in section 2.1, except that the source of iron was mixed with $400 \mu \mathrm{M}$ of rhodamine B. Bacteria grow 7 days longer in the presence than in the absence of rhodamine B. Although whole magnetotactic bacteria as well as magnetosome chain arrangement and magnetosome shapes appear to be relatively similar for bacteria grown in the absence or presence of rhodamine B as shown in the TEM images of Figs. 1(a), 1(b), 1(d), 1(e), magnetosome sizes appear to be larger by $30-40 \%$ in the presence than in the absence of rhodamine B (Figs. 1(c) and 1(f)). This behavior may be attributed to the chelation of iron by rhodamine B that facilitates the introduction of iron inside magnetotactic bacteria. ${ }^{38}$ Following growth, magnetosomes were extracted and separated from organic debris as described in section 2.1 for non-fluorescent magnetosomes and we obtained a suspension of fluorescent magnetosomes designated as MCR400 in which rhodamine B was associated to magnetosomes.

\subsection{Preparation of non-dissociating probe: Synthesis of fluorescent magnetosomes, designated as}

\section{MC@RhB-1, by chemically associating rhodamine B to chains of magnetosomes extracted from}

magnetotactic bacteria. $30 \mathrm{mg}$ of rhodamine $\mathrm{B}$ was mixed with $3 \mathrm{~mL}$ of distilled water to produce a solution of rhodamine B at $0.0626 \mathrm{mmol}$. This solution was introduced in a three-necked round-bottom flask equipped with a thermometer, a condenser, a pH-meter, and a magnetic stirrer. Aqueous $\mathrm{HCl}$ solution $(1 \mathrm{~N})$ was added drop wise at $0^{\circ} \mathrm{C}$ to reach a $\mathrm{pH}$ of 4.5 . Then, $24 \mathrm{mg}$ of $\mathrm{EDC}$ ((3- 
(Éthyliminométhylidèneamino)-N,N-diméthylpropan-1-amine) at $0.156 \mathrm{mmol}$ and $18 \mathrm{mg}$ of NHS ((1hydroxypyrrolidine-2,5-dione) at $0.156 \mathrm{mmol}$ were successively added to the rhodamine B solution kept at $0^{\circ} \mathrm{C}$ and $\mathrm{pH}=4.5$. The rhodamine $\mathrm{B}$ reaction mixture was then stirred for $4 \mathrm{~h}$ at $0^{\circ} \mathrm{C}$ and $\mathrm{pH}=4.5 .10$ $\mathrm{mL}$ of a suspension of $\mathrm{pH}=11.5$ containing $3 \mathrm{mg}$ of chains of magnetosomes extracted from magnetotactic bacteria $(\mathrm{CM})$ mixed in distilled water were sonicated and added to the rhodamine B reaction mixture. $\mathrm{pH}$ was maintained at 11.5 using a $1 \mathrm{~N}$ aqueous $\mathrm{NaOH}$ solution. The mixture was then stirred at $60^{\circ} \mathrm{C}$ during $22 \mathrm{~h}$. Then, the reaction was stopped by addition of an aqueous $1 \mathrm{~N} \mathrm{HCl}$ solution until $\mathrm{pH}=7$ was reached. Magnetosomes associated to rhodamine B, designated as MC@RhB-1, were then concentrated using a strong Neodymium magnet ( 0.6 Tesla), re-suspended in $10 \mathrm{~mL}$ of sterile water and washed several times with sterile water using a magnet to isolate $\mathrm{MC} @ \mathrm{RhB}-1$ from free rhodamine B. Finally, we used a chromatographic SEPHADEX G-25 gel (GE Healthcare, Buckimghamshire, UK) to isolate MC@RhB-1 from free residual compounds such as urea.

\subsection{Preparation of non-dissociating probes: Synthesis of MC@RhB-2, by adsorbing rhodamine B} at the surface of chains of magnetosomes extracted from magnetotactic bacteria. Suspensions of non-fluorescent chains of magnetosomes extracted from magnetotactic bacteria (MC) at $28 \mu \mathrm{g} / \mathrm{mL}$ in iron were mixed with a rhodamine B solution at four different concentrations of $120 \mathrm{ng} / \mathrm{mL}, 240 \mathrm{ng} / \mathrm{mL}$, $3 \mu \mathrm{g} / \mathrm{mL}$ and $4 \mu \mathrm{g} / \mathrm{mL}$ at $\mathrm{pH}$ 8. The mixed suspensions contained in $1 \mathrm{~mL}$ were sonicated using a finger at $5 \mathrm{~W}$ and $40^{\circ} \mathrm{C}$ during 2 hours. Magnetososomes were magnetically separated from the supernate 12 times using a Neodinim magnet as described above. Following each separation step, the supernate containing free rhodamine in excess was removed and nanoparticles were re-suspended in water. For the lowest quantity of rhodamine B of $120 \mathrm{ng}$, we did not observe any significant peak from rhodamine B in the absorption spectra of the mixed suspensions after 1 or 12 separation steps (Fig. S2(a)). When the quantity of rhodamine B was increased, the spectra of MC mixed with rhodamine B followed by one separation step show a peak at rhodamine B absorption wavelength for quantities of rhodamine B of 240 ng (Fig. S2(b)), $2.6 \mu \mathrm{g}$ (Figs. S2(c)), $3.9 \mu \mathrm{g}$ (Fig. S2(d)). However, this peak disappears after 12 
separation steps (Figs. S2(b) to S2(d)), indicating that rhodamine B is not adsorbed to the magnetosomes in MC@RhB-2.

\subsection{Type of fluorescent magnetosomes that can be used as dissociating probe.}

To prepare the suspensions containing the three-different fluorescent magnetosomes, MCR400, MC@RhB-1, and MC@RhB-2, we isolated the nanoparticles from the supernate of the nanoparticle suspensions by positioning a Neodymium magnet against the Eppendorf tube containing $1 \mathrm{~mL}$ of these suspensions, we removed the supernate that we replaced by $1 \mathrm{~mL}$ of water. This corresponded to the first separation step and this step was repeated 12 times. During each separation step, we measured the optical density of the supernate at $550 \mathrm{~nm}$ to examine the presence or not of rhodamine $\mathrm{B}$ in the supernate. Fig. 2(a) shows that the optical density of the supernate either progressively decreases between the first and fifth separation step to becomes negligible afterwards for MCR400 and MC@RhB-1 or disappears immediately after the first separation step for MC@RhB-2. This indicates that after 12 separation steps, the supernates of the three nanoparticle suspensions do not contain any rhodamine B. Given that we define the association between rhodamine B and the magnetosomes as that, which can withstand magnetic separation, we deduce that after 12 separation steps if rhodamine B molecules remain in MCR400, MC@RhB-1, and MC@RhB-2 suspensions, they are associated with the magnetosomes. After 12 separation steps, the signal of fluorescence of the supernate was negligible at the emission wavelengths of rhodamine B, confirming the absence of free rhodamine B in the supernate. We further examine if the suspensions containing MCR400, MC@RhB-1, and MC@RhB-2, which were obtained after 12 separation steps, can be used as a dissociating probe. In both absorption and fluorescent spectra of MC@RhB-2, rhodamine B peaks are absent (Figs. 2(b) and 2(c)), indicating that rhodamine B has not associated to the magnetosomes in this sample (Fig. S2) and that MC@RhB-2 can therefore not be used as fluorescent probe. By contrast, for $\mathrm{MC} @ \mathrm{RhB}-1$, although the absorption spectrum is similar to that of MC (Fig. 2(b)), suggesting that large numbers of rhodamine B molecules are not associated to the magnetosomes, the fluorescence spectrum of MC@RhB-1 is similar to that of rhodamine B (Fig. 2(c)), indicating that rhodamine B is associated to the magnetosomes in MC@RhB-1. 
However, when we heated the MC@RhB-1 suspension during 30 minutes at $90{ }^{\circ} \mathrm{C}$, collected its supernate by magnetic separation and measured the absorption spectrum of the supernate (Fig. 3(a)), we observed that the absorption peak of rhodamine B was absent (Fig. 3(a)), suggesting that rhodamine B has not dissociated from the magnetosomes following heating and that MC@RhB-1 could therefore not be used as a dissociating probe. For MCR400, the association of rhodamine B to the magnetosomes was highlighted on the one hand by the absorption spectrum of the MCR400 suspension, which displays a shoulder at $550 \mathrm{~nm}$ corresponding to the maximum absorption wavelength of rhodamine B (Fig. 2(b)) and by the fluorescence emission spectrum of the same suspension, which shows a peak with maximum fluorescence intensity at $569 \mathrm{~nm}$ (Fig. 2(c)), a wavelength that is slightly lower than that corresponding to the maximum fluorescence intensity of rhodamine B at $581 \mathrm{~nm}$ (Fig. 2(c)). Indeed, the difference in emission wavelength between free rhodamine and MCR400 could be explained by the association of rhodamine $\mathrm{B}$ to the nanoparticles, since this type of shift has previously been observed with fluorophores entrapped into nanoparticles. ${ }^{38}$ Furthermore, when the MCR400 suspension was heated during 30 minutes at $90{ }^{\circ} \mathrm{C}$ and its supernate was magnetically separated from the nanoparticles, we measured that the absorption of the supernate displays a peak at $555 \mathrm{~nm}$ (Fig. 3(b)), a similar wavelength as that of free rhodamine B (Fig. 2(b)), indicating that rhodamine B has dissociated from the magnetosomes after heating and that MCR400 could therefore be used as a dissociating probe.

\subsection{Quantity of rhodamine B associated to magnetosomes in MCR400.}

To further characterize MCR400, we determined the number of rhodamine B molecules associated to each magnetosome in MCR400. For that, the $\mathrm{pH}$ of the MCR400 suspension was decreased to 2 using hydrochloric acid, leading to the release of rhodamine B from the magnetosomes. The fluorescence and absorption properties of MCR400 and free rhodamine B brought to $\mathrm{pH} 2$ are presented in Fig. S3. The spectrum of MCR400 at pH 2 (Fig. S2(c)) shows a peak at $582 \mathrm{~nm}$, which corresponds to the emission wavelength of free rhodamine $\mathrm{B}$ in solution at $\mathrm{pH} 2$, confirming that rhodamine $\mathrm{B}$ has been released from the magnetosomes after a change in $\mathrm{pH}$. From the intensity of this peak of $\sim 0.56$ a.u (Fig. S2(c)), we have deduced a rhodamine $\mathrm{B}$ concentration of $750 \mathrm{nmol} / \mathrm{L}$ using a calibration curve, which 
represents the variation of rhodamine $\mathrm{B}$ fluorescence intensity at $\mathrm{pH}=2$ as a function rhodamine $\mathrm{B}$ concentration (Fig. S2(a)). Given a magnetosome concentration of $166 \mu \mathrm{g} / \mathrm{mL}$, a magnetosome weight of $6.25 \times 10^{-16} \mathrm{~g}$, a number of rhodamine B molecules and magnetosomes per $\mathrm{mL}$ of $4.6 \times 10^{14}$ and $26.5 \times 10^{10}$, respectively, we have deduced that $178 \pm 4$ rhodamine B molecules were associated to each magnetosome on average. Rhodamine B molecules are more likely adsorbed at magnetosome surface to enable their release within the magnetosome surrounding environment, but vacancies may also be present in the magnetosome mineral crystal core, which could possibly be filled with rhodamine B molecules.

\subsection{Dissociation of rhodamine $B$ from the magnetosomes with increasing temperatures in suspensions of MCR400.}

To examine if rhodamine $\mathrm{B}$ dissociation from the magnetosomes is enhanced with increasing temperature, we first measured the optical density at $550 \mathrm{~nm}$ of the supernates of MCR400 suspensions, which were heated at $20{ }^{\circ} \mathrm{C}$ to $90{ }^{\circ} \mathrm{C}$ for 0 to 240 minutes. For the three heating temperatures of $20{ }^{\circ} \mathrm{C}$, $60{ }^{\circ} \mathrm{C}$, and $90{ }^{\circ} \mathrm{C}$, the optical density at the absorption wavelength of rhodamine $\mathrm{B}(550 \mathrm{~nm})$ of the supernate of MCR400 has been measured as a function of heating time. For these three temperatures, Fig. 3(c) shows that the optical density saturates after 100 minutes of heating at $0.004\left(20{ }^{\circ} \mathrm{C}\right)$, at 0.028 $\left(60{ }^{\circ} \mathrm{C}\right)$, at $0.048\left(90{ }^{\circ} \mathrm{C}\right)$. To make sure that saturation was reached, MCR400 suspensions were then heated during 240 minutes at various temperatures and we observed that rhodamine B concentration in the supernate of MCR400 increased from $20 \mathrm{nM}$ at $20{ }^{\circ} \mathrm{C}$ to $560 \mathrm{nM}$ at $90{ }^{\circ} \mathrm{C}$, where these concentrations were determined using the calibration curve of free rhodamine B (Fig. S3(b)). Given that 41.5 molecules of rhodamine B per magnetosomes are in the supernate at $90{ }^{\circ} \mathrm{C}$, and that there are 178 rhodamine $\mathrm{B}$ molecules per magnetosome before heating, we deduce that $23 \%$ of rhodamine $\mathrm{B}$ have dissociated from the magnetosomes at $90^{\circ} \mathrm{C}$.

We then studied if MCR400 could be used as a fluorescent temperature probe. For that, we measured the fluorescence spectra of a MCR400 suspension heated at $20^{\circ} \mathrm{C}, 35^{\circ} \mathrm{C}, 50^{\circ} \mathrm{C}, 65^{\circ} \mathrm{C}$, and $80{ }^{\circ} \mathrm{C}(\mathrm{Fig}$. 3(e)) and we observed that the maximum fluorescence intensity of the emission peak, at $569 \mathrm{~nm}$, 
strongly increases by $66 \%$ (Fig. 3(e)) with increasing temperature, a behavior which is the opposite to that of free rhodamine B whose fluorescence intensity is observed to sharply decrease by $73 \%$ with increasing temperature within this temperature range, (Fig 3(f)). ${ }^{39}$ In MCR400, the fluorescence intensity of rhodamine B would initially be attenuated when rhodamine B is associated to the magnetosomes, most probably due to quenching by iron oxide ${ }^{40}$, and would then increase when rhodamine $\mathrm{B}$ dissociates from the magnetosomes with increasing temperature. Using the relation between MCR400 fluorescence intensity and temperature, it therefore appears feasible to use MCR400 fluorescence as a temperature probe.

\subsection{Dissociation of rhodamine B from the magnetosomes by exposing MCR400 to radiation.}

To examine if rhodamine $\mathrm{B}$ dissociates from the magnetosomes under radiation, we have irradiated a suspension of MCR400 at doses ranging from 0 Gy to $1350 \mathrm{~Gy}$. The supernate of this suspension was isolated from the nanoparticles by magnetic separation and we measured its fluorescence intensity at 578 $\mathrm{nm}$, corresponding to the emission wavelength of free rhodamine B. The fluorescence intensity was observed to strongly increase by a factor of $\sim 2-4$ from 200-300 a.u. in the absence of irradiation to 600900 a.u. at 300-1350 Gy (Fig. 4). Given that the luminescence intensity of free rhodamine B does not vary with increasing radiations (Fig. 4), the behavior of MCR400 observed in Fig. 4 could be attributed to the dissociation of rhodamine B from the magnetosomes under radiations.

\subsection{Dissociation of rhodamine $B$ from the magnetosomes at acidic $\mathrm{pH}$ in MCR400 suspensions}

Next, to examine if MCR400 can be used as a pH probe, we have adjusted the pH of a MCR400 suspension containing $400 \mu \mathrm{g} / \mathrm{mL}$ of iron oxide to values between 2 and 12 by adding a 0.1 to $12 \mathrm{M}$ hydrochloric acid or sodium hydroxide solution. The samples containing the treated MCR400 were then placed against a magnet of $0.6 \mathrm{~T}$ for $12 \mathrm{~h}$ at $4{ }^{\circ} \mathrm{C}$ and the supernate was collected. At acidic $\mathrm{pH}$, the maximum fluorescence intensity of MCR400 and of its supernate increases with decreasing pH (Fig. 5(a)), a behavior opposite to that observed for free rhodamine B suggesting that MCR400 release free rhodamine $\mathrm{B}$ in the supernate at acidic $\mathrm{pH}$. Between $\mathrm{pH} 8$ and 12, the fluorescence intensity of the MCR400 suspension and of its supernate increase much less than at acidic pH (Fig. 5(a)). These 
behaviors suggest that rhodamine B dissociates from MCR400 much more significantly at acidic than basic $\mathrm{pH}$. This conclusion is further supported by the analysis of the wavelength variation with $\mathrm{pH}$. Indeed, at basic $\mathrm{pH}(\mathrm{pH}>7)$, we observe that the emission wavelength of MCR400 is lower than that of free rhodamine B or of MCR400 supernate, suggesting that most rhodamine B molecules have not been dissociated from the magnetosomes to yield free rhodamine B. In this case, MCR400 may have formed a complex containing magnetosomes and rhodamine B. By contrast, at acidic $\mathrm{pH}(\mathrm{pH}<7)$, Fig. 5(b) shows that the emission wavelengths of MCR 400 increases with decreasing $\mathrm{pH}$ to reach the same value as that of free rhodamine at $\mathrm{pH}$ 2. To conclude, MCR400 may be used to locally measure $\mathrm{pH}$ in acidic but not basic conditions.

\subsection{MCR400 as in vitro probe.}

Zymosan-elicited, peritoneal macrophages can rapidly internalize MCR400, presumably by phagocytosis. Fig 6 (a) shows that red fluorescent MCR400 particles accumulate in intracellular vesicles macrophage. Another type of cell was used to determine if this behavior could be generalized to different cell types. As shown in Fig. 6(b), when MCR400 are incubated with TC1-GFP tumor cells for 15 minutes, fluorescence imaging reveals the same localized red spots as in Fig. 6(a). It clearly appears that these intracellular vesicles are cytoplasmic, and not nuclear. Further evidence of the localization of the magnetosomes inside intracellular vesicles was provided by an electron microscopy image of a TC1GFP incubated with MCR400 (Fig. 6(c)), which clearly shows that magnetosomes are concentrated in intracellular vesicles (an assembly of 18 magnetosomes in this case) and not dispersed in the cytoplasm.

\subsection{MCR400 as in vivo probe}

For the different rats, fluorescent spectra of the healthy areas without MCR400, presented in Figures 7(a) to $7(\mathrm{~d})$, are very similar with a broad peak of maximum intensity at $\sim 500 \mathrm{~nm}$, which is attributed to the combination of nicotinamide dinucleotide (NADH) and flavins (FAD), occurring at $450 \mathrm{~nm}$ and 525 nm, respectively. ${ }^{38,41}$ This peak display three shoulder at $575 \mathrm{~nm}, 625 \mathrm{~nm}$, and $690 \mathrm{~nm}$, possibly due to the fluorescence of the lipopigments, the porphyrins and the chlorins respectively. ${ }^{43}$ The spectra of the healthy areas were averaged, thus making it possible to normalize all the fluorescence spectra measured 
for all the slices of rat brain. The auto-fluorescent spectra of tumor areas appear to be similar than those of healthy areas, except that peak intensities are weaker. For rat 3 euthanized two hours following MCR400 administration, the fluorescence spectrum of the tumor region, in which MCR400 were administrated, show the presence of two interesting peaks, at $569 \mathrm{~nm}$ and $576 \mathrm{~nm}$ which are either absent or less intense relatively to the emission at $500 \mathrm{~nm}$ in the spectra of the tumor and healthy regions. We attribute these two peaks to the emission of MCR400 at $569 \mathrm{~nm}$ which was similar in solution and to that of rhodamine B and lipo-pigment at $576 \mathrm{~nm}$, both emitting at this wavelength. In the region containing MCR400, the peak at $576 \mathrm{~nm}$ can not only be due to the endogenous fluorescence of the lipopigments, since its fluorescence intensity at $576 \mathrm{~nm}$ relatively to that at $500 \mathrm{~nm}, \mathrm{I}_{576} / \mathrm{I}_{500} \sim 1$, is higher than that of $\mathrm{I}_{576} / \mathrm{I}_{500} \sim 0.5$ measured for healthy and tumor areas without MCR400. For rat 4 euthanized four days following MCR400 administration, the fluorescence spectrum of the tumor region with MCR400 also shows a peak at $576 \mathrm{~nm}$ with enhanced intensity, suggesting the presence of free rhodamine B released from the magnetosomes. The peak at $569 \mathrm{~nm}$ attributed to MCR400 has disappeared, which could be due the dissociation of all rhodamine B from the magnetosomes 4 days after MCR400 administration.

\section{CONCLUSION:}

In conclusion, we have shown that intruding $400 \mu \mathrm{M}$ of rhodamine $\mathrm{B}$ in the growth medium of AMB-1 magnetotactic bacteria leads to the production of magnetosomes of larger sizes than in the absence of rhodamine B, possibly due to the chelation of iron by rhodamine B. After extraction form magnetotactic bacteria, these magnetosomes appear to be fluorescent with absorption and emission peaks at similar wavelengths than those of free rhodamine $\mathrm{B}$. When they are heated to $30-90{ }^{\circ} \mathrm{C}$, brought to acidic $\mathrm{pH}$, or exposed to radiations (> $300 \mathrm{~Gy}$ ), these magnetosomes also appear to release rhodamine B. Furthermore, when they are mixed in vitro with tumor cells (TC1-GFP or RG2 cells) or introduced in the brains of rats, fluorescence intensity is enhanced at rhodamine $\mathrm{B}$ emission wavelength, possibly due to magnetosomes being captured by cells which may in turn lead to rhodamine B release. We have developed a fluorescent probe that works by dissociation of the fluorescent molecules (rhodamine B) 
from the nanoparticles (magnetosomes). Compared with other fluorescent probes without any dissociating mechanism, our probe presents the advantage of potentially enabling the simultaneous monitoring and control of drug release from nanoparticles. Such probe was not described before. ${ }^{43}$ Since typical commonly used cancer drugs such as doxorubicin have a similar molecular weight than rhodamine B and possess chelating chemical functions, it is possible to imagine that they could replace rhodamine B and improve the magnetic hyperthermia treatment of tumors, by combing the effect of heat with that of drug activation. ${ }^{44,45,46}$

Acknowledgment: We would like to thank the Eurostars program (Nanoneck2, E9309), subvention AIR from the region of Paris (A1401025Q), the ANR Méfisto as well as the ANRT (CIFRE 2014/0359). Edouard Alphandéry wrote the article and directed the research described in this article. 


\section{REFERENCES:}

1. Chekina, N.; Horák, D.; Jendelová, P.; Trchová, M.; Beneš, M.-J.; Hrubý, M.; Herynek, V.; Turnovcova, K.; Sykova, E. Fluorescent magnetic nanoparticles for biomedical applications. J. Mater Chem. 2011, 21, 7630-9.

2. Benjaminsen, R.-V.; Sun, H.; Henriksen, J.-R.; Christensen, N.-M.; Almdal, K.; Andresen, T.-L.; Evaluating Nanoparticle Sensor Design for Intracellular pH Measurements. ACS Nano. 2011, 26,58645873.

3. Bai, Z.; Chen, R.; Si, P.; Huang, Y.; Sun, H.; Kim, D.-H. Fluorescent pH Sensor Based on Ag@SiO2 Core-Shell Nanoparticle. ACS Appl Mater Interfaces. 2013, 5, 5856-60.

4. Susha, A.-S.; Javier, A.-M.; Parak, W.-J.; Rogach A.-L. Luminescent CdTe nanocrystals as ion probes and $\mathrm{pH}$ sensors in aqueous solutions. Colloids and Surfaces A: Physicochemical and Engineering Aspects.Colloids AND Surfaces A. 2006, 281, 40-43.

5. Bertorelle, F.; Wilhelm, C.; Roger, J.; Gazeau, F.; Ménager, C.; Cabuil, V. FluorescenceModified Superparamagnetic Nanoparticles: Intracellular Uptake and Use in Cellular Imaging. Langmuir. 2006, 22, 5385-5391.

6. Li, X.; Chen L. Fluorescence Probe Based on an Amino-Functionalized Fluorescent Magnetic Nanocomposite for Detection of Folic Acid in Serum. ACS Appl. Mater Interfaces. 2016, 8, 3183231840 .

7. Basuki, J.-S.; Duong, H.-T.-T.; Macmillan, A.; Erlich, R.-B.; Esser, L.; Akerfeldt, M.-C..; Megan W.-R.; Kavallaris, M.; Boyer, C.; Davis T.-P.. Using Fluorescence Lifetime Imaging Microscopy to Monitor Theranostic Nanoparticle Uptake and Intracellular Doxorubicin Release. ACS Nano. 2013, 7, 10175-101789. 
8. Chen, J.; Zheng, A.; Chen, A.; Gao, Y.; He, C.; Kai, X.; Wu, G.; Chen, Y. A functionalized gold nanoparticles and Rhodamine 6G based fluorescent sensor for high sensitive and selective detection of mercury(II) in environmental water samples. Analytica Chimica Acta. 2007, 599, 134-142.

9. Arai, S.; Lee, S.-C.; Zhai, D.; Suzuki, M.; Chang, Y.-T. A Molecular Fluorescent Probe for Targeted Visualization of Temperature at the Endoplasmic Reticulum. Scientific Reports. 2014, 4, 6701.

10. Freddi, S.; Sironi, L.; D’Antuono, R.; Morone, D.; Donà, A.; Cabrini, E.; D'Alfonso, L.; Collini, M.; Pallavicini, P.; Baldi, G.; Maggioni, D.; Chirico, G.; A Molecular Thermometer for Nanoparticles for Optical Hyperthermia. Nano Lett. 2013, 13, 2004-2010.

11. Cui, J.; Kwon, JE.; Kim, H-J.; Whang, DR.; Park, SY. Smart Fluorescent Nanoparticles in Water Showing Temperature-Dependent Ratiometric Fluorescence Color Change. ACS Appl Mater Interfaces. 2017, 9, 2883-2890.

12. Ali, H.; Bhunia, S.-K.; Dalal, C.; Jana, N.-R. Red Fluorescent Carbon Nanoparticle-Based Cell Imaging Probe. ACS Appl Mater Interfaces. 2016, 8, 9305-9313.

13. Das, P.; Jana, N.-R.; Highly Colloidally Stable Hyperbranched Polyglycerol Grafted Red Fluorescent Silicon Nanoparticle as Bioimaging Probe. ACS Appl Mater Interfaces. 2014, 6, 4301-4309.

14. Fan, Z.; Sun, L.; Huang, Y.; Wang, Y.; Zhang, M. Bioinspired fluorescent dipeptide nanoparticles for targeted cancer cell imaging and real-time monitoring of drug release. Nat. Nano. 2016, 11, 388-394.

15. Wolfbeis O.-S. An overview of nanoparticles commonly used in fluorescent bioimaging. Chemical Society Reviews. 2015, 44, 4743-4368.

16. Colby, A.-H.; Berry, S.-M.; Moran, A.-M.; Pasion, K.-A.; Liu, R.; Colson, Y.-L.; Ruiz-Opazo, N.; Grinstaff, M.-W.; Herrera, V.-L. Highly Specific and Sensitive Fluorescent Nanoprobes for ImageGuided Resection of Sub-Millimeter Peritoneal Tumors. ACS Nano. 2017, 11, 1466-1477. 
17. Al-Kady, A.-S.; Gaber, M.; Hussein, M.-M.; Ebeid, E.-Z.-M. Structural and fluorescence quenching characterization of hematite nanoparticles. Spectrochimica Acta Part A: Molecular and Biomolecular Spectroscopy. 2011, 83, 398-405.

18. Yu, C-J.; Wu, S.-M.; Tseng, W.-L. Magnetite Nanoparticle-Induced Fluorescence Quenching of Adenosine Triphosphate-BODIPY Conjugates: Application to Adenosine Triphosphate and Pyrophosphate Sensing. Anal Chem. 2013, 85, 8559-65.

19. Simard, B.; Tomanek, B.; Van Veggel, F.-C.-J.-M.; Abulrob, A. Optimal dye-quencher pairs for the design of an "activatable" nanoprobe for optical imaging. Photochem. Photobiol Sci. 2013, 12, $1824-1829$.

20. Lei, G.; Gao, P.-F.; Yang, T.; Zhou, J.; Zhang, H.-Z.; Sun, S.-S.; Gao, M.-X.; Zhi Huang C. Photoinduced Electron Transfer Process Visualized on Single Silver Nanoparticles. ACS Nano. 2017, 11, 2085-2093.

21. Alphandéry, E.; Walsh, L.-M.; Rakovich, Y.; Bradley, A.-L.; Donegan, J.-F.; Gaponik, N. Highly efficient Förster resonance energy transfer between CdTe nanocrystals and Rhodamine B in mixed solid films. Chemical Physics Letters. 2004, 388, 100-104.

22. Sapsford, K.-E.; Berti, L.; Medintz, I.-L. Materials for Fluorescence Resonance Energy Transfer Analysis: Beyond Traditional Donor-Acceptor Combinations. Angewandte Chemie International Edition. 2006, 45, 4562-4589.

23. Pal, M.; Rakshit, R.; Mandal, K. Surface Modification of MnFe2O4 Nanoparticles to Impart Intrinsic Multiple Fluorescence and Novel Photocatalytic Properties. ACS Appl Mater Interfaces. 2014, $6,4903-4910$. 
24. Hong, H.; Wang, F.; Zhang, Y.; Graves, S.-A.; Eddine, S.-B.-Z.; Yang, Y.; Theuer, C.-P.; Nickles, R.-J.; Wang, X.; Cai, W. Red Fluorescent Zinc Oxide Nanoparticle: A Novel Platform for Cancer Targeting. ACS Appl Mater Interfaces. 2015, 7, 3373-3381.

25. Tan, X.; Wang, J.; Pang, X.; Liu, L.; Sun, Q.; You, Q.; Tan, F.; Li, N. Indocyanine GreenLoaded Silver Nanoparticle@Polyaniline Core/Shell Theranostic Nanocomposites for Photoacoustic/Near-Infrared Fluorescence Imaging-Guided and Single-Light-Triggered Photothermal and Photodynamic Therapy. ACS Appl Mater Interfaces. 2016, 8, 34991-35003.

26. Bazylinski, D.-A.; Frankel, R.-B. Magnetosome formation in prokaryotes. Nat Rev Micro. 2004, $2,217-230$.

27. Alphandéry, E.; Faure, S.; Seksek, O.; Guyot, F.; Chebbi, I. Chains of Magnetosomes Extracted from AMB-1 Magnetotactic Bacteria for Application in Alternative Magnetic Field Cancer Therapy. ACS Nano. 2011, 5, 6279-6296.

28. Alphandéry, E.; Chebbi, I.; Guyot, F.; Durand-Dubief M. Use of bacterial magnetosomes in the magnetic hyperthermia treatment of tumours: A review. International Journal of Hyperthermia. 2013, $29,801-809$.

29. Alphandéry, E. Applications of Magnetosomes Synthesized by Magnetotactic Bacteria in Medicine. Front. Bioeng. Biotechnol. [Internet]. 2014 Mar 11 [cited 2017 May 26];2. Available from: http://www.ncbi.nlm.nih.gov/pmc/articles/PMC4126476/

30. Alphandéry, E.; Lijeour, L.; Lalatonne, Y.; Motte, L. Different signatures between chemically and biologically synthesized nanoparticles in a magnetic sensor: A new technology for multiparametric detection. Sensors and Actuators B: Chemical. 2010, 147, 786-790.

31. Lang, C.; Schüler, D. Expression of Green Fluorescent Protein Fused to Magnetosome Proteins in Microaerophilic Magnetotactic Bacteria. Appl. Environ. Microbiol. 2008, 74, 4944-4953. 
32. Carillo, M.-A.; Bennet, M.; Faivre D. Interaction of Proteins Associated with the Magnetosome Assembly in Magnetotactic Bacteria As Revealed by Two-Hybrid Two-Photon Excitation Fluorescence Lifetime Imaging Microscopy Förster Resonance Energy Transfer. J. Phys. Chem. B. 2013, 117, 1464214648.

33. Tang, T.; Zhang, L.; Gao, R.; Dai, Y.; Meng, F.; Li, Y. Fluorescence imaging and targeted distribution of bacterial magnetic particles in nude mice. Appl. Microbiol. Biotechnol. 2012, 94, 495503.

34. Alphandéry, E.; Amor, M.; Guyot, F.; Chebbi, I. The effect of iron-chelating agents on Magnetospirillum magneticum strain AMB-1: Stimulated growth and magnetosome production and improved magnetosome heating properties. Appl. Microbiol. Biotechnol. 2012, 96, 663-670.

35. Leh, B.; Siebert, R.; Hamzeh, H.; Menard, L.; Duval, M-A.; Charon, Y.; Abi-Haidar, D. Optical phantoms with variable properties and geometries for diffuse and fluorescence optical spectroscopy. $J$ Biomed Opt. 2012, 17, 108001.

36. Thoreau M.; Penny, H.-L.; Tan, K.; Regnier, F.; Weiss, J.-M.; Lee, B.; Johannes, L.; Dransart, E.; Le Bon, A.; Abastado, J.-P.; Tartour, E.; Trautmann, A.; Bercovici, N. Vaccine-induced tumor regression requires a dynamic cooperation between $\mathrm{T}$ cells and myeloid cells at the tumor site. Oncotarget. 2015, 6, 27832-27846.

37. Alphandéry, E. Perspectives of Breast Cancer Thermotherapies. J. Cancer. 2014, 5, 472-479.

38. Auger, A.; Samuel, J.; Poncelet, O.; Raccurt, O. A comparative study of non-covalent encapsulation methods for organic dyes into silica nanoparticles. Nanoscale Research Letters. 2011, 6, 328.

39. Kubin, R.-F.; Fletcher, A.-N. Fluorescence quantum yields of some rhodamine dyes. Journal of Luminescence. 1982, 27, 455-62. 
40. Turro, N.-J.; Lakshminarasimhan, P.-H.; Jockusch, S.; O’Brien, S.-P.; Grancharov, S.-G.; Redl, F.-X. Spectroscopic Probe of the Surface of Iron Oxide Nanocrystals. Nano Lett. 2002, 2, 325-328.

41. Huang, S.; Heikal, A.-A.; Webb, W.-W. Two-photon fluorescence spectroscopy and microscopy of NAD(P)H and flavoprotein. Biophys J. 2002, 82, 2811-2825.

42. Haidar, D.-A.; Leh, B.; Zanello, M.; Siebert, R. Spectral and lifetime domain measurements of rat brain tumors. Biomed Opt Express. 2015, 6, 1219-1233.

43. Hergta, R.; Hiergeista, R.; Zeisbergera, M.; Schuler, D.; Heyen, U.; Hilger, I.; Kaiser, W.-A. Magnetic properties of bacterial magnetosomes as potential diagnostic and therapeutic tools. J. Magn. Magn. Mat. 2005, 293, 80-86.

44. Le Fèvre1, R.; Durand-Dubief, M.; Chebbi, I.; Mandawla, C.; Lagroix, F.; Valet, J-P.; Idbaih, A.; Adam, C.; Delttre, J-Y.; Scmitt, C.; Maake, C.; Guyot, F.; Alphandéry, E. Enhanced antitumor efficacy of biocompatible magnetosomes for the magnetic hyperthermia treatment of glioblastoma. Theranostics. 2017, doi:10.7150/thno.18927.

45. Alphandéry, E.; Idbaih, A.; Adam, C.; Delattre, J-Y.; Schmitt, C.; Guyot, F.; Chebbi, I. Chains of magnetosomes with controlled endotoxin release and partial tumor occupation induce full destruction of intracranial U87-Luc glioma in mice under the application of an alternating magnetic field. J. Controlled. Release. 2007, 262, 259-272.

46. Alphandéry, E.; Idbaih, A.; Adam, C.; Delattre, J-Y.; Schmitt, C.; Guyot, F.; Chebbi, I. Development of non-pyrogenic magnetosome minerals coated with poly-L-lysine leading to full disapperance of intracranial U87-Luc glioblastoma in 100\% of treated mice using magnetic hyperthermia. Biomaterials. 2017, 141, 210-222. 


\section{CAPTIONS AND FIGURES:}

Scheme 1: Schematic diagrams showing the steps involved in the preparations of: (a), the dissociating probe (MCR400) obtained by cultivating magnetotactic bacteria in the presence of $400 \mu \mathrm{M}$ of rhodamine B and by extracting fluorescent chains of magnetosomes from these bacteria, (b), the nondissociating probe (MC@RhB-1) obtained by extracting chains of magnetosomes from magnetotactic bacteria and by chemically attaching rhodamine B to the chains of magnetosomes, (c), the nondissociating probe (MC@RhB-2) obtained by extracting chains of magnetosomes from magnetotactic bacteria and by adsorbing rhodamine B to the chains of magnetosomes.

Figure 1: For magnetotactic bacteria cultivated in the presence of $400 \mu \mathrm{M}$ of rhodamine $\mathrm{B}$, electron microscopic images of a whole magnetotactic bacterium, (a), a chain of magnetosomes contained inside 
such bacterium, (b), and a histogram representing magnetosome size distribution inside such bacterium, (c). For magnetotactic bacteria cultivated in the absence of rhodamine B, electron microscopic images of a whole magnetotactic bacterium, (d), a chain of magnetosomes contained inside such bacterium, (e), and a histogram representing magnetosome size distribution inside such bacterium, (f). In (c) and (f), the histogram were realized on 300 magnetosomes (20 bacteria).

Figure 2: (a), variation of the optical density, measured at $550 \mathrm{~nm}$, of the supernate of $1 \mathrm{~mL}$ suspensions containing $400 \mu \mathrm{g}$ of MC@RhB-1, MC@RhB-2, MCR400, as a function of the number of separation step. (b), Absorption spectra of $1 \mathrm{~mL}$ suspensions containing $40 \mu \mathrm{g}$ of MC, MCR400, MC@RhB-1, MC@RhB-2, or $4 \mu \mathrm{g}$ of rhodamine B. The intensity of the MC@RhB-1 is divided by a factor of 1.6. (c), Fluorescence spectra, excited at $405 \mathrm{~nm}$, of $800 \mu \mathrm{L}$ suspensions containing $166 \mu \mathrm{g}$ of MC, MCR400, MC@RhB-1, MC@RhB-2, or $0.4 \mu \mathrm{g}$ of rhodamine B.

Figure 3: Absorption spectra of $1 \mathrm{~mL}$ suspensions containing $40 \mu \mathrm{g}$ of MC@RhB-1, the supernate of this suspension obtained after magnetic separation, (a), a $1 \mathrm{~mL}$ suspension containing $40 \mu \mathrm{g}$ of MCR400, the supernate of this suspension obtained after magnetic separation, (b), where the MCR400 and MC@RhB-1 suspensions have been heated at $90{ }^{\circ} \mathrm{C}$ during 15 minutes. (c), Optical density, measured at $550 \mathrm{~nm}$, of the supernate of a $1 \mathrm{~mL}$ suspension containing $40 \mu \mathrm{g}$ of MCR 400 collected after the MCR400 suspension has been heated at $20^{\circ} \mathrm{C}, 60{ }^{\circ} \mathrm{C}, 90^{\circ} \mathrm{C}$ for different times varied between 0 and 240 minutes. (d), Concentration of rhodamine B in the supernate of a $1 \mathrm{~mL}$ suspension containing $40 \mu \mathrm{g}$ of MCR400 collected after the MCR400 suspension has been heated at 20 to $90{ }^{\circ} \mathrm{C}$ during 240 minutes. (e), Fluorescence spectra, excited at $405 \mathrm{~nm}$, of $1 \mathrm{~mL}$ suspensions containing $166 \mu \mathrm{g}$ of MCR400, which have been heated at various temperatures of $20{ }^{\circ} \mathrm{C}, 35^{\circ} \mathrm{C}, 50{ }^{\circ} \mathrm{C}, 65^{\circ} \mathrm{C}, 80{ }^{\circ} \mathrm{C}$, during 15 minutes. (f), Fluorescence spectra, excited at $405 \mathrm{~nm}$, of $1 \mathrm{~mL}$ suspensions containing $40 \mu \mathrm{g}$ of rhodamine $\mathrm{B}$, which have been heated at various temperatures of $20^{\circ} \mathrm{C}, 40^{\circ} \mathrm{C}, 60^{\circ} \mathrm{C}, 80^{\circ} \mathrm{C}$, during 15 minutes. 
Figure 4: Fluorescence intensity, excited at $405 \mathrm{~nm}$, measured at $576 \mathrm{~nm}$, of the supernate of $1 \mathrm{~mL}$ suspensions containing $400 \mu \mathrm{g}$ of MCR400 or $40 \mu \mathrm{g}$ of free rhodamine B following irradiation at different doses varied between 0 Gy and 1350 Gy.

Figure 5: (a), Maximum fluorescence intensity of fluorescence spectra of $1 \mathrm{~mL}$ suspensions containing $400 \mu \mathrm{g}$ of MCR400, the supernate of this suspension, or $40 \mu \mathrm{g}$ of rhodamine $\mathrm{B}$, excited at $405 \mathrm{~nm}$ and measured between $550 \mathrm{~nm}$ and $650 \mathrm{~nm}$ as a function of the $\mathrm{pH}$ of these suspensions varied between 2 and 12. (b), For the same suspensions, wavelength corresponding to the maximum fluorescence intensity as a function of the $\mathrm{pH}$ of these suspensions varied between 2 and 12.

Figure 6: MCR400 magnetosomes can efficiently be endocytosed or phagocytosed by macrophages and in tumor cells. (a), Zymozan-activated murine peritoneal macrophages were incubated with rhodaminecoupled MCR400 and imaged with a fluorescent optical microscope with excitation at $560 \mathrm{~nm}$ and 607 $\mathrm{nm}$ detection. During the first hour, a red fluorescence increased in the cells, under the form of red spots (yellow arrows) presumably corresponding to phagosomes. (b), TC1-GFP tumor cells incubated with MCR400 were imaged in the same conditions, plus the appropriate GFP filters (485 and $525 \mathrm{~nm}$ ). Within less than an hour, the red fluorescence increased in the cytoplasm of TC1-GFP cells. (c), TEM image of a U87-Luc cell incubated with MCR400 for 15 minutes, where the cell was included in a resin and cut in an $80 \mathrm{~nm}$ thick slide with a microtome. The zoom represents a cell compartment, possibly a lysosome, phagosome, or endosome, containing MCR400.

Figure 7: Fluorescence spectra of different section of rat brain with an excitation at $405 \mathrm{~nm}$ and an emission between 400 et $725 \mathrm{~nm}$. Spectra of two regions of a healthy brain without MCR400 administration, (a), Spectra of tumor region and healthy region without MCR400 administration, (b), Spectra of tumor region containing or not MCR400 and an Healthy region without MCR400, for a rat euthanized two hours following MCR400 administration (c), Spectra of tumor region containing or not MCR400 and an Healthy region without MCR400, for a rat euthanized 4 days following MCR400 administration, (d). 
(a) Preparation of dissociating probe (MCR400)

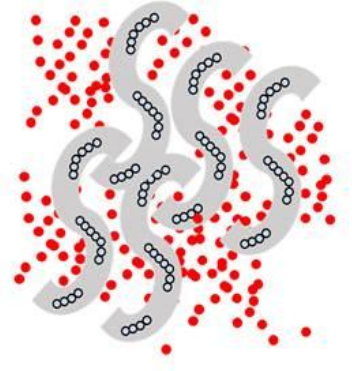

AMB-1 Bacteria in media culture with $400 \mu \mathrm{M}$ of Rhodamine B

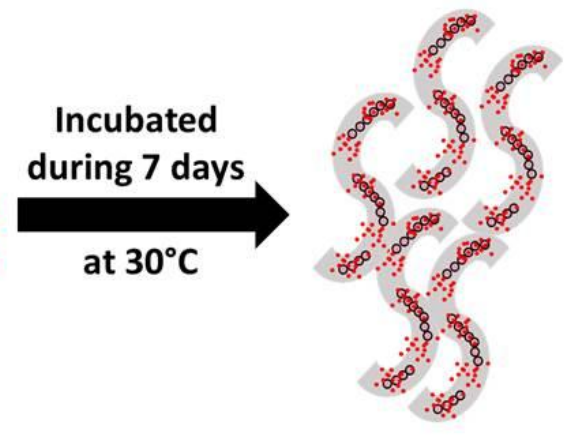

AMB-1 Bacteria with rhodamine $B$ washed by PBS

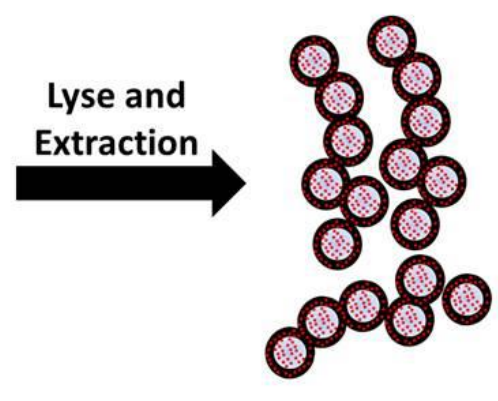

MCR400

(b) Preparation of non-dissociating probe (MC@RhB-1)
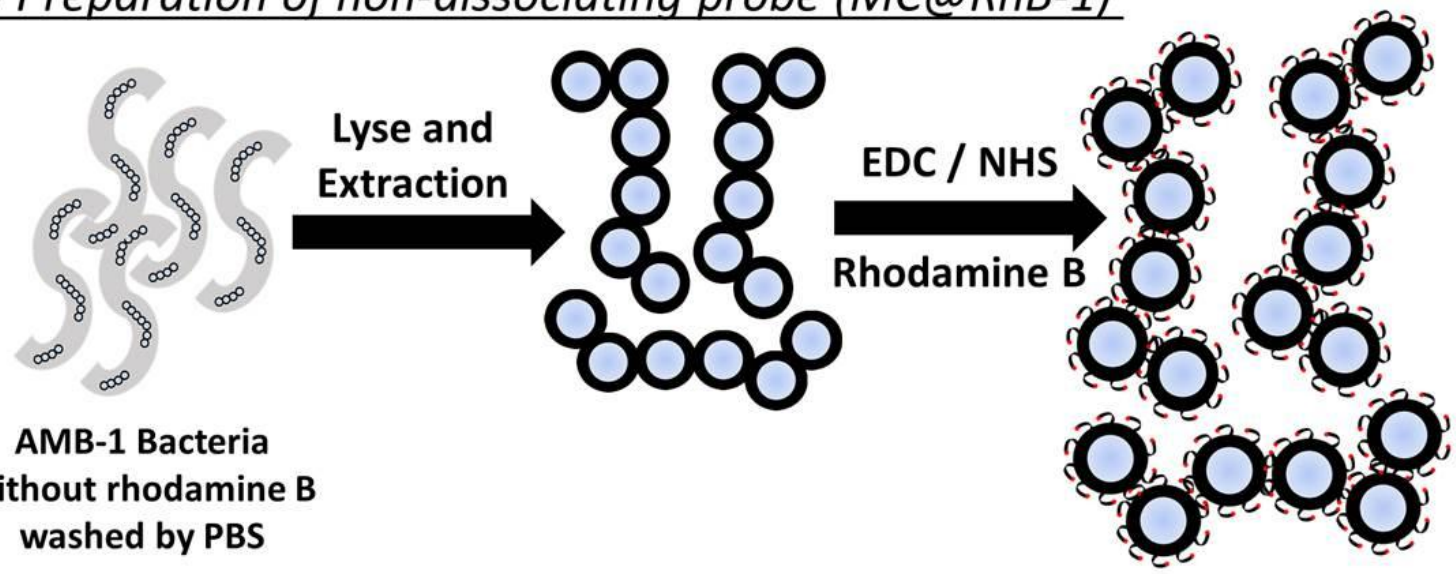

AMB-1 Bacteria without rhodamine $B$ washed by PBS

Chemical attachement of the rhodamine $B$ to $M C$ (MC@RhB-1)

(c) Preparation of non-dissociating probe (MC@RhB-2)

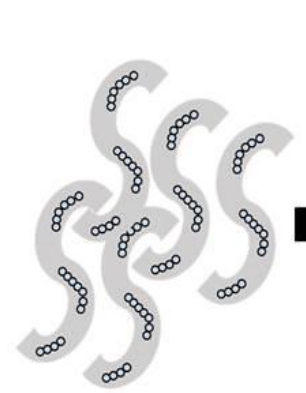

AMB-1 Bacteria without rhodamine $B$ washed by PBS

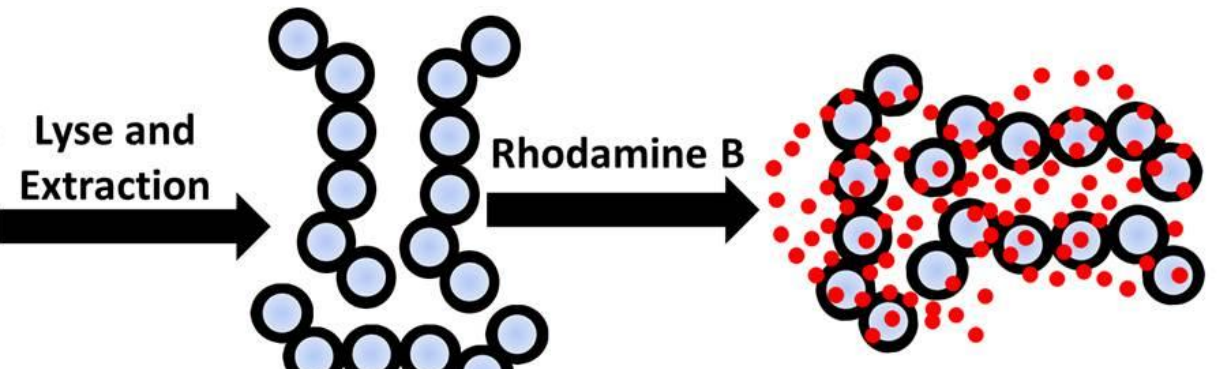

Rhodamine B adsorption to the surface of MC (MC@RhB-2) 


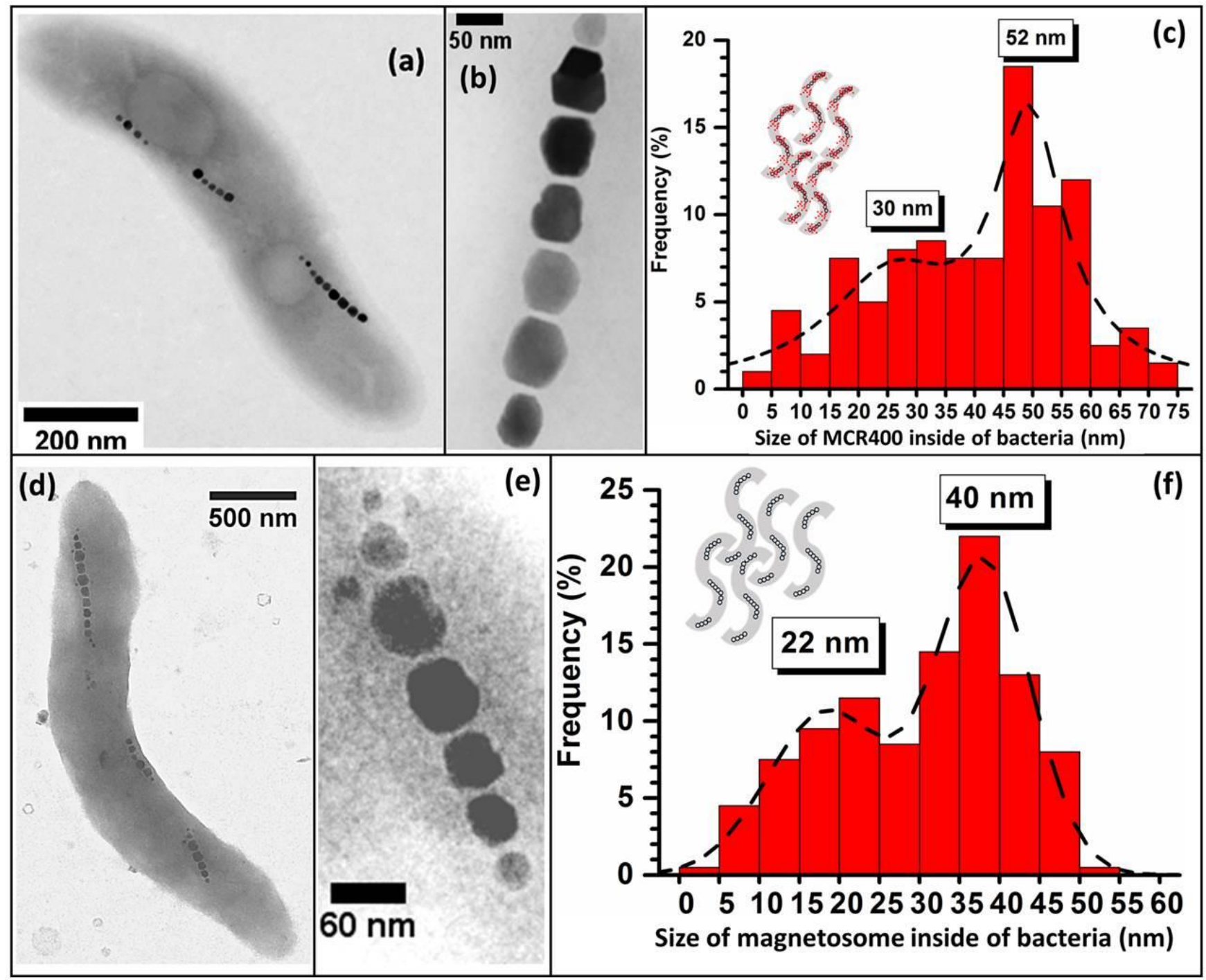

Figure 1 


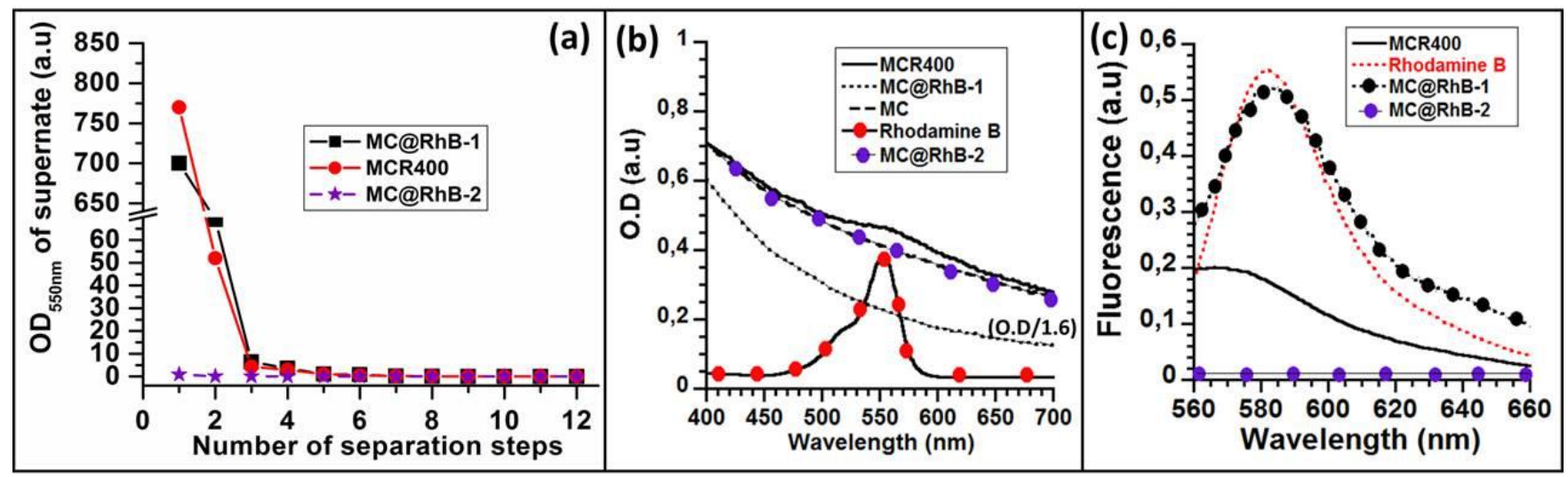

Figure 2 


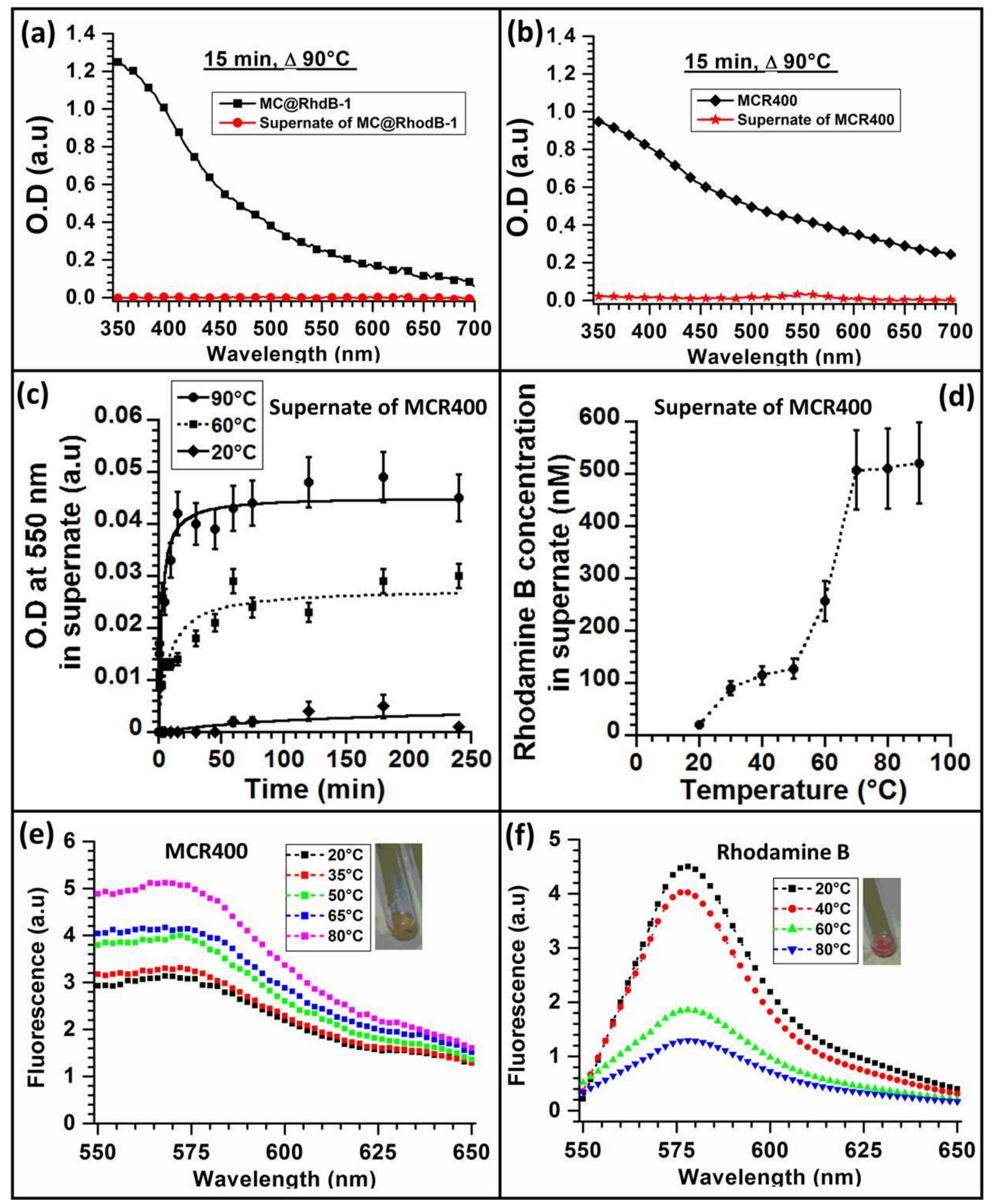

Figure 3 


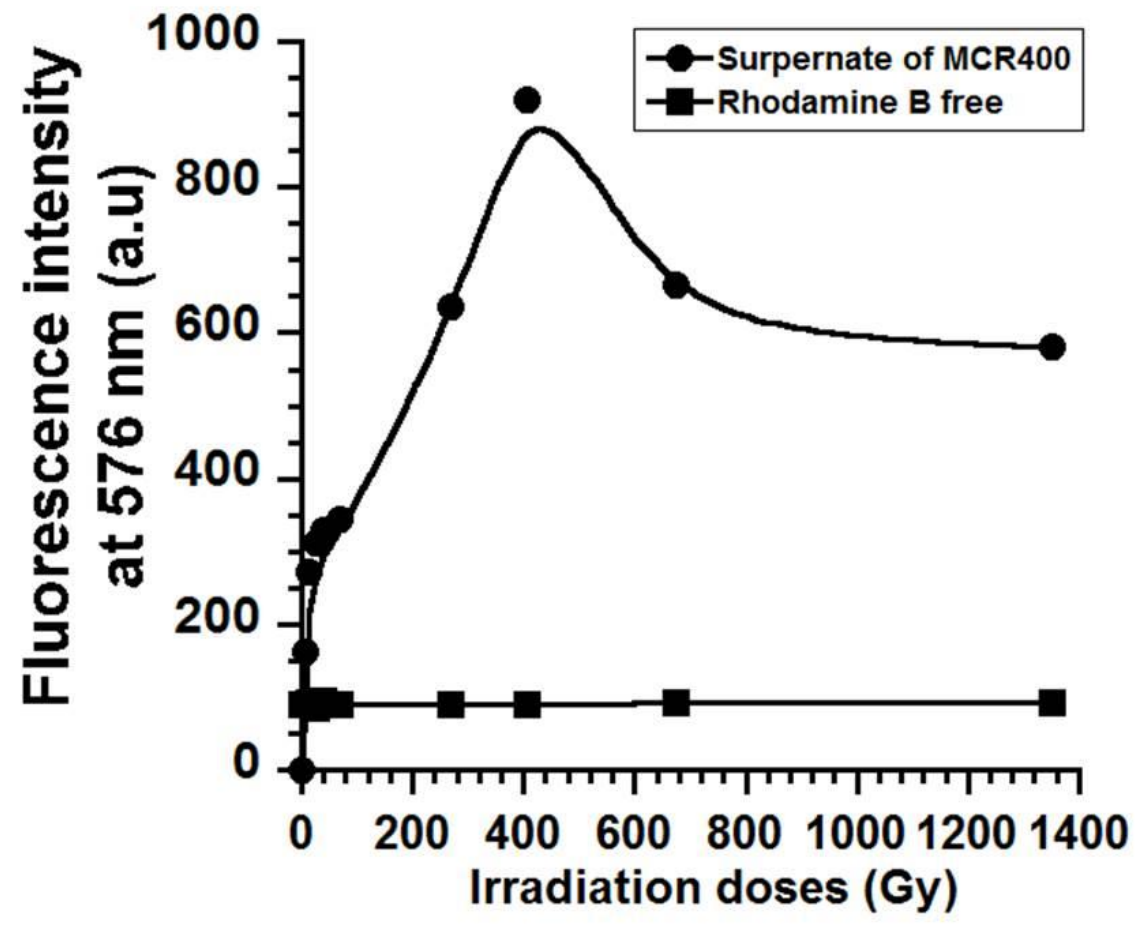

Figure 4 


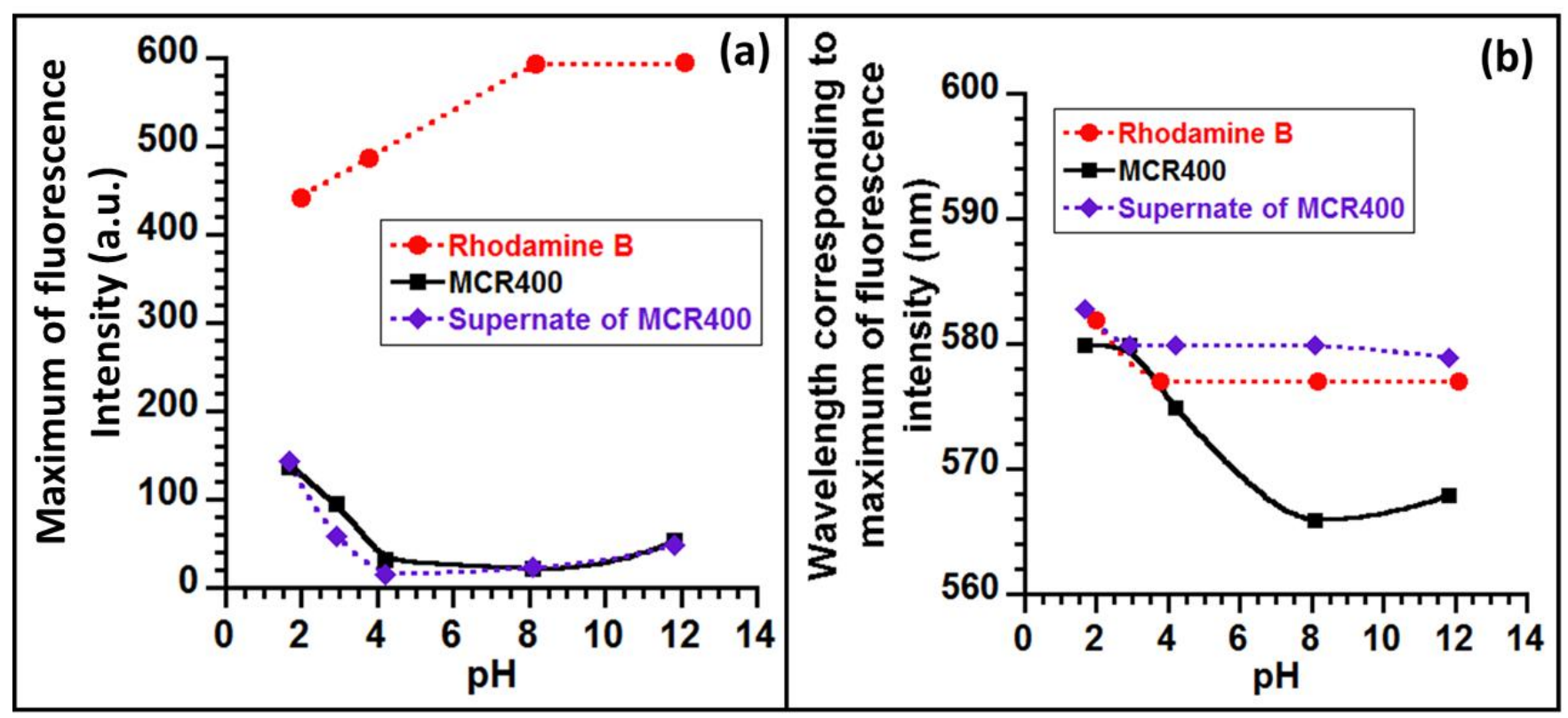

Figure 5 


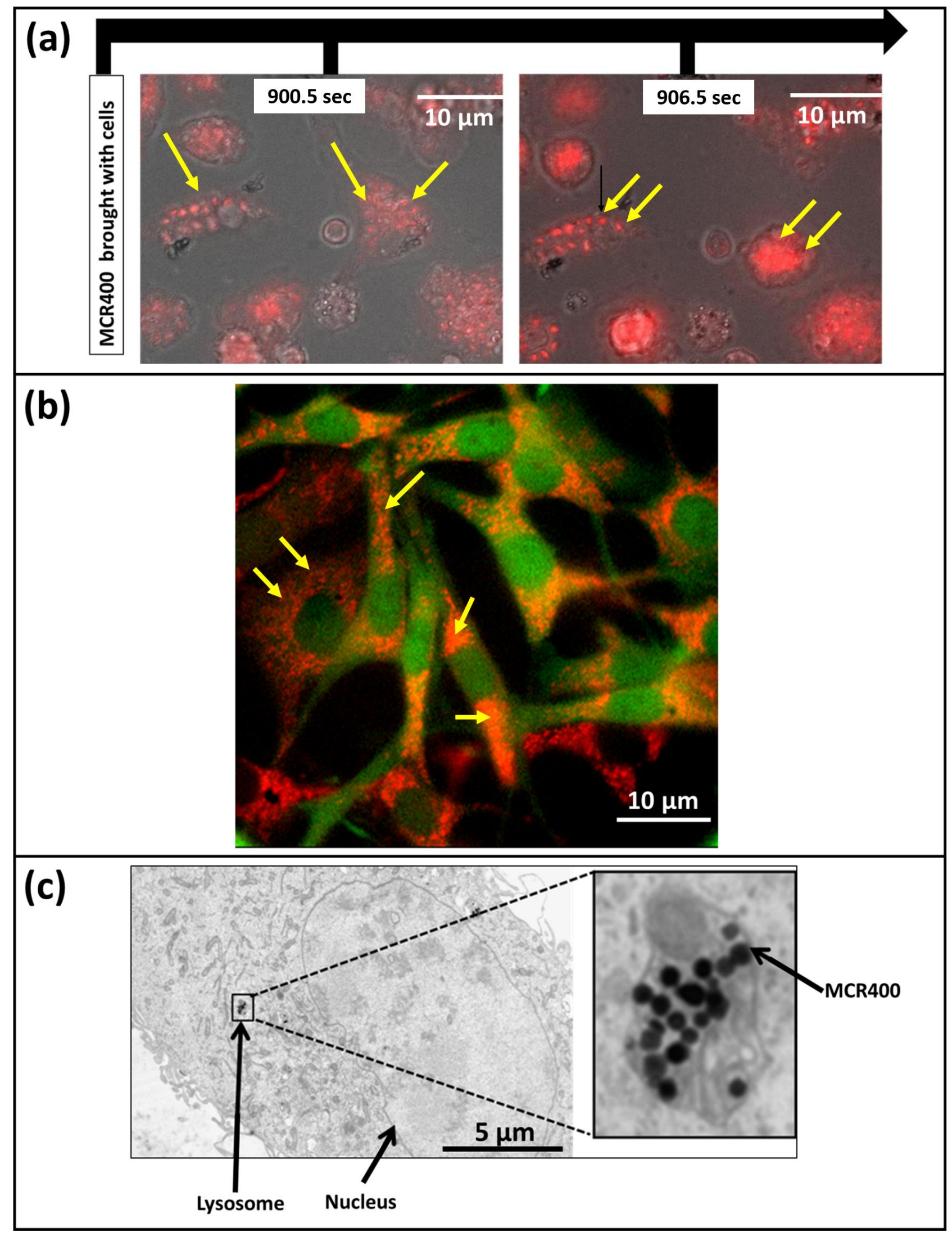

Figure 6 


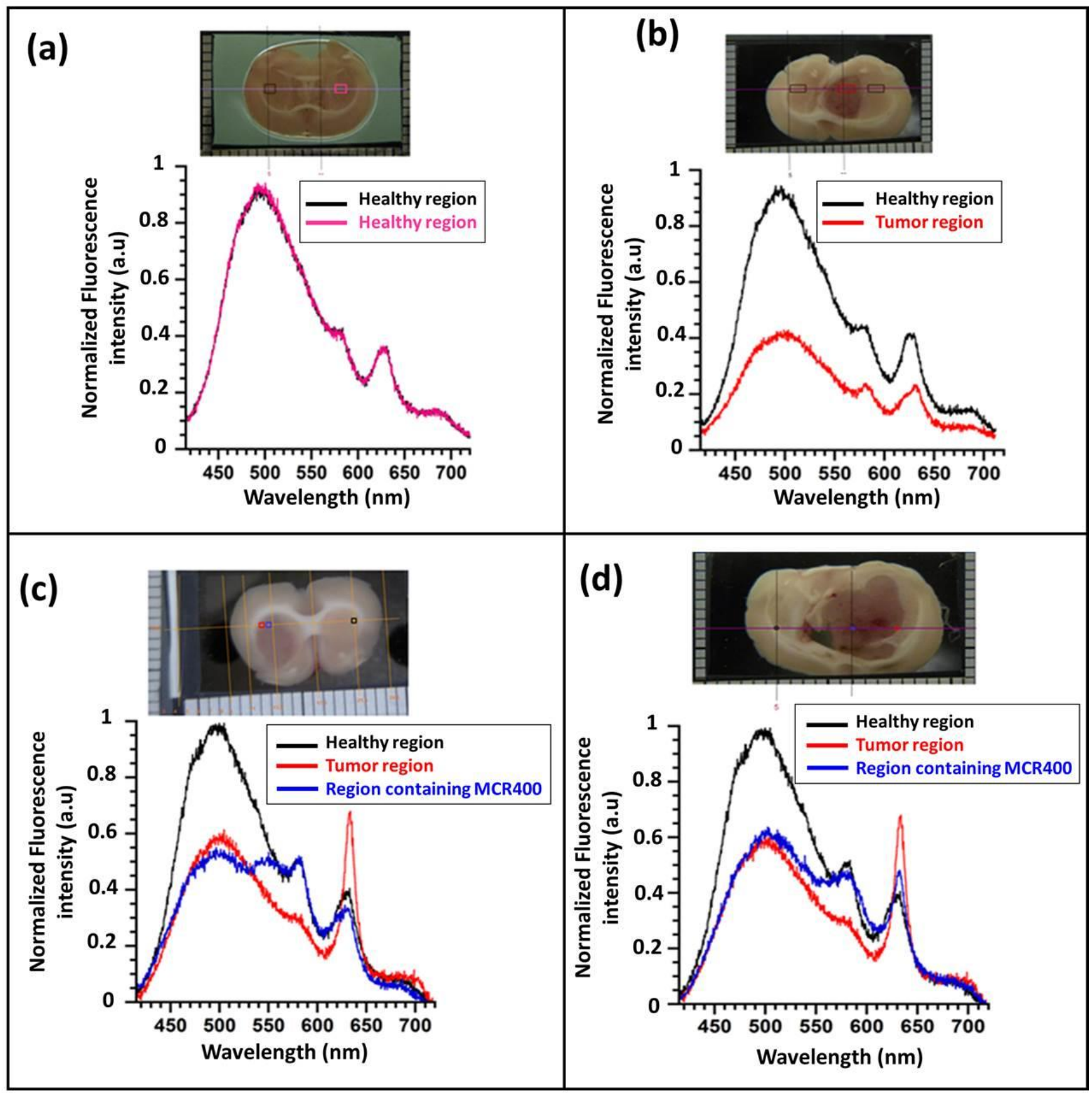

Figure 7 